\title{
Estimation of Aquifer Transmissivity Using Dar Zarrouk Parameters Derived from Surface Resistivity Measurements: A Case History from Parts of Enugu Town (Nigeria)
}

\author{
Ahamefula U. Utom, Benard I. Odoh, Anthony U. Okoro \\ Department of Geological Sciences, Nnamdi Azikiwe University, Awka, Nigeria \\ Email: greatgraham2@yahoo.com
}

Received September 2, 2012; revised October 6, 2012; accepted October 13, 2012

\begin{abstract}
Many investigation techniques are commonly employed with the aim of estimating the spatial distribution of transmissivity. Unfortunately, the conventional methods for the determination of hydraulic parameters such as pumping tests, permeameter measurements and grain size analysis are invasive and relatively expensive. A geoelectric investigation involving vertical electrical sounding was carried in parts of Enugu town, Enugu state, Nigeria. The survey was aimed at extrapolating the result of pumping tests over an area. Using the Dar Zarrouk parameter, a $\beta$ constant of 0.32 was found to translate resistivity to transmissivity with clay content as the primary factor controlling the hydraulic conductivity. Results of the study show a strong correlation between aquifer transmissivity and longitudinal conductance $\left(\mathrm{R}^{2}=\right.$ 0.82). Estimation of aquifer transmissivity values based on the results of the resistivity measurements also made it possible to demarcate area with good groundwater potential in parts of Enugu town, Nigeria.
\end{abstract}

Keywords: Resistivity; Transmissivity; Dar Zarrouk Parameters; Longitudinal Conductance; Pumping Tests

\section{Introduction}

As groundwater becomes more important as a source of uncontaminated water, improved hydrogeological knowledge, new groundwater exploration technologies and data processing methods must be efficient to facilitate investigations and evaluation of groundwater resources $[1,2]$. Many investigation techniques are commonly employed with the aim of estimating the spatial distribution of aquifer parameters such as hydraulic conductivity, transmissivity and aquifer depth [3]. Unfortunately, the conventional methods for the determination of hydraulic parameters such as pumping tests, permeameter measurements and grain size analysis are invasive, relatively expensive and either integrate over a largest volume of data or provide information only to a small section of the aquifer in the vicinity of the borehole [4,5]. According [6] interpolating aquifer properties between boreholes is often difficult with little or no data in which to base these extrapolations. Therefore, in areas with few pumping test information, the spatial distribution of aquifer properties cannot be confidently calculated. The application of surface resistivity method however, can provide useful method for obtaining information on aquifer properties in areas where pumping test data are sparse and subsurface conditions area appropriate.

Surface resistivity techniques are a useful tool routinely used under a variety of field conditions and geological settings in hydrogeology, environmental geology and geotechnical engineering [7,8,10-14]. Details on effective sampling rate and high quality data requirements for high target definition in an area geometrically constrained with complex subsurface conditions using resistivity techniques are suggested in $[16,17]$.

Geophysicists have realized that the integration of aquifer parameters calculated from existing borehole locations and subsurface resistivity parameters extracted from resistivity measurements can be highly effective, since a correlation between hydraulic and electrical aquifer properties can be possible as both properties are related to the pore space structure and heterogeneity [1, 18,19]. A number of outstanding papers and reports have been published on the application of resistivity techniques in evaluating the relationships between aquifer electrical and hydraulic properties [5,20-24]. For this purpose transformation of the aquifer resistivity distribution in terms of the aquifer Dar Zarrouk parameters requires the application of physically consequential relation derived either theoretically or empirically $[25,26]$. 
The main thrust of this paper is therefore to use surface resistivity sounding in extrapolating pumping test results over an area, by estimating transmissivity from resistivity data in parts of Enugu town, where intermittent water supply and shortages are major problems of the inhabitants.

\section{Relationship between Transmissivity and the Dar Zarrouk Parameters}

Groundwater flow through an aquifer is not governed by hydraulic conductivity, $K$ alone, but the bulk parameter transmissivity, defined as:

$$
K * h
$$

where $h$ is the thickness of the aquifer. Attempts have been made to relate hydraulic conductivity to resistivity for specific aquifers, usually glacial deposits [e.g., 27-30]. Both direct and inverse relationships have been shown to exist. [31,32] theoretically derived two equations using Ohm's law of current flow and Darcy's law for fluid flow in a medium as:

$$
\begin{gathered}
T_{h}=\alpha R ; K_{h}=\alpha \rho[\text { for } K \alpha \phi] \\
T_{h}=\beta C ; K_{h}=\beta / \rho\left[\text { for } K \alpha \frac{1}{\text { Clay content }}\right]
\end{gathered}
$$

where, $T_{h}$ is the transmissivity, $K_{h}$ is the hydraulic conductivity, $\rho$ is the electrical resistivity, $R\left(\Omega \cdot \mathrm{m}^{2}\right)$ is the transverse unit resistance, $C\left(\Omega^{-1}\right)$ is the longitudinal unit conductance of the aquifer and $\alpha$ and $\beta$ are the constants of proportionality.

The Dar Zarrouk Parameters (DZP) defined by the longitudinal unit conductance in $\Omega^{-1}(C$, layer thickness over resistivity) and transverse unit resistance in $\Omega \cdot \mathrm{m}^{2}(\mathrm{R}$, layer thickness times resistivity) are also two of the most important parameters in electrical prospecting [34,35]. Since Dar Zarrouk parameters are also bulk parameters, taking the relationship between hydraulic conductivity and resistivity a stage further leads to a relation between transmissivity values estimated from pumping tests and the Dar Zarrouk parameters from surface resistivity measurement as shown in Equations (2) and (3). This minimizes the problems arising from the non-uniqueness of surface resistivity interpretation. While dealing with basic equations of direct current prospecting, [34] observed that if one considers a geologic column built on a square unit (Figure 1), $R$ is the resistance to the lines of current perpendicular to the strata, and, $C$ is the conductance to the lines of current parallel to the strata. These theoretical relationships showing direct and inverse correlation between hydraulic conductivity and electrical resistivity has been explained with respect to four basic assumptions $[5,6]$ :
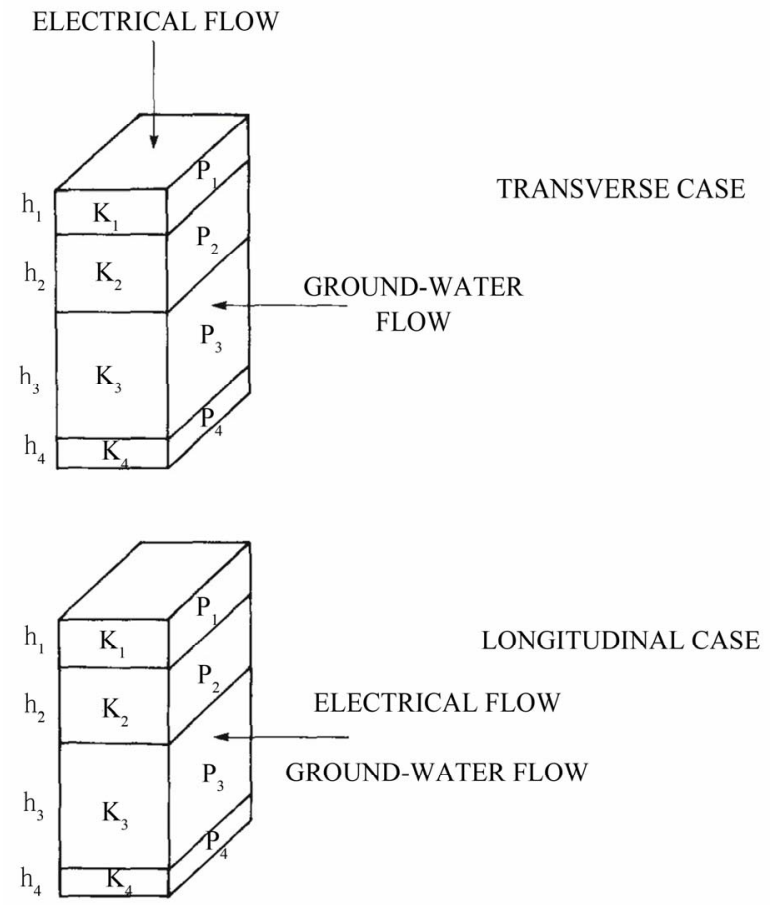

Figure 1. Layered models showing transverse resistance and longitudinal conductance [33].

1) In the case of a conducting basement, the hydraulic conductivity is directly proportional to the electrical resistivity: this applicable to Equation (1) (Figure 2);

2) In the case of a resistive basement, the hydraulic conducting is inversely: this is applicable to Equation (2) (Figure 2);

3) In the case of an unconsolidated, sandy, clay-free aquifer, the hydraulic conductivity is directly related to the porosity [36] and inversely related to the electrical resistivity: this is applicable to Equation (1);

4) In the case of a clay-rich aquifer, the relationship between porosity breaks down in a more a complex manner leaving clay content as the primary factor controlling hydraulic conductivity: this is applicable to Equation (2).

As a condition in sandy clay free hydrogeological environment, $K \rho$ can be considered constant; in clay-rich environment $K / \rho$ should remain constant. The electrical conductivity of the groundwater is expected not to vary significantly throughout the aquifer as this would also affect the measured resistivity. According to [5] sometimes this condition for using Equations (2) or (3) may be difficult to meet. The authors further advised that it is also essential that a priori hydraulic conductivity information at least one point be known before using the equations.

Using a representative average hydraulic conductivity of $77.5 \mathrm{~m} / \mathrm{d}$ [37] for 13 existing wells in the area, the transmissivity in the study were estimated using Equation 


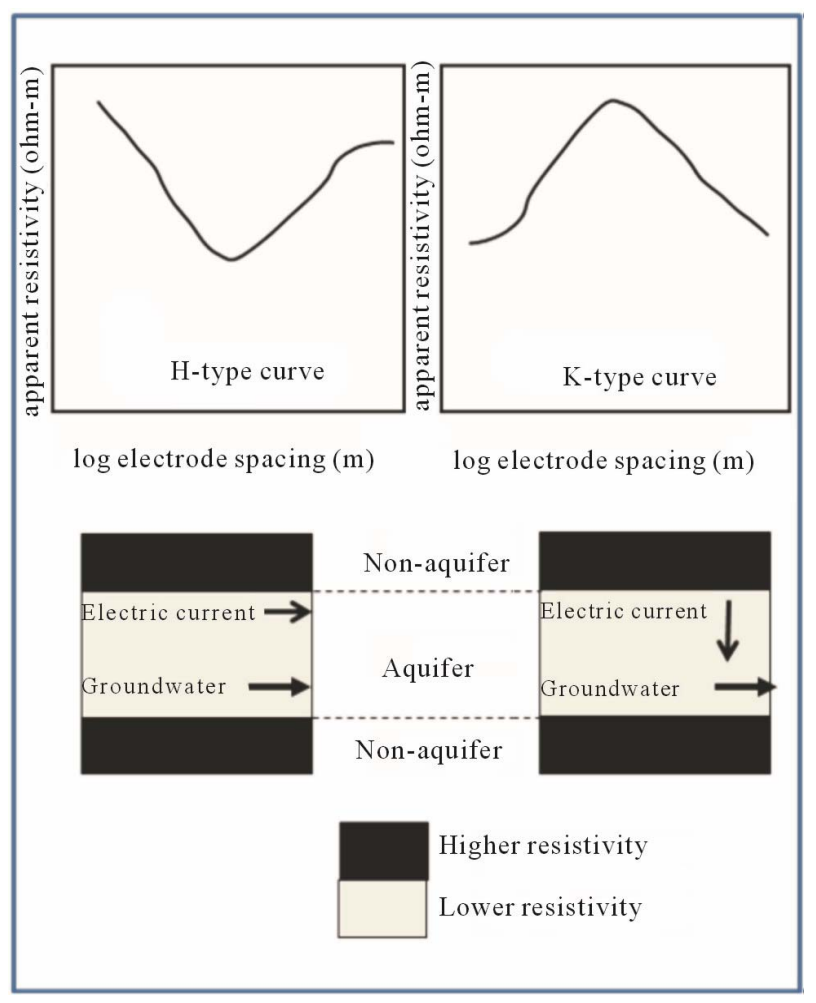

Figure 2. Characteristic shapes of $\mathbf{K}$ - and H-type resistivity curves [6].

(1). This average hydraulic conductivity values compared favourably well with the work of [38] in the area. The authors used the relation [39] for parallel flow within each lithologic layer represented by point flow values:

$$
K_{Z}=b /\left(\sum_{i=1}^{m}\left(b_{i} / k_{i}\right)\right)
$$

where, $K_{i}$ is the hydraulic conductivity of each individual layer of thickness, $b_{i}$ (ranging from $1 \mathrm{~m}$ to $60 \mathrm{~m}$ ) with a total number of 13 layers; $b$ is the overall thickness of the sequence (about $130 \mathrm{~m}$ ). These hydraulic conductivity values in the range of $10^{-5}-10^{-2} \mathrm{~m} / \mathrm{s}$ are characteristic of a silty sand and clean sand aquifer [40].

Hence, in establishing the electrical nature of the basement layer from resistivity sounding curves, we chose Equation (3) to estimate the aquifer transmissivity from the aquifer electrical parameters. This analogous and empirical relationship can then assist in the estimation of transmissivity using longitudinal conductance by surface geoelectrical data, provided the aforementioned basic assumptions are satisfied.

\section{Site Information and Geoelectric Method}

The Enugu area study site is located between latitudes $06^{\circ} 22^{\prime} \mathrm{N}$ and $06^{\circ} 27^{\prime} \mathrm{N}$ and longitudes $007^{\circ} 25^{\prime} \mathrm{E}$ and $007^{\circ} 30^{\prime} \mathrm{E}$ at about $5 \mathrm{~km}$ west of Enugu city and about 15 $\mathrm{km}$ near Akanu Ibiam International Airport at Enugu North L.G.A in the southeastern Nigeria's Enugu state. The site area extent is approximately $84 \mathrm{~km}^{2}$.

The study area has three predominant and conformable geologic formations (Figure 3): The Campanian Enugu Shale, the Lower Maestrichtian Mamu Formation and the Upper Maestrichtian Ajali Sandstone. Stratigraphically, the Enugu Shale which overlies the Cross River Plain east of the escarpment is overlain by the Mamu Formation which in turn is overlain by the Ajali Formation. Hydrology and hydrogeology of the area is controlled by topographic features. In the study area, the streams or rivers, some of which appear fracture-controlled in their flow path give rise to dendritic drainage pattern. The topography and physiography affect the position and shape of groundwater tables. The Enugu's climate is humid and humidity is high during rains. The average annual precipitation in Enugu is estimated to be 2000 mm (79 in.) which arrives intermittently and becomes very heavy during the rainy season. For the whole of Enugu state, the mean daily temperature is $26.7^{\circ} \mathrm{C}$ $\left(80.1^{\circ} \mathrm{F}\right)$ [41]. The Sahara air mass, north-easterly dry winds causes the dry season (October to March) as it advances southwards while the Atlantic Ocean air mass causes the rainy season (March to October) as it moves northwards [42]. Water resources availability is also limited due to the spatiotemporal variation of precipitation. The area receives domestic water supply from river reservoirs and the Ninth Mile Corner borehole network. At present, it is a general practice that nearly very single house built outside the municipal area drill a groundwater well for its own domestic use. The wells are generally drilled by local and small-scale contractors where scientific data gathered are of secondary importance.

During this work, 19 geoelectrical soundings with a maximum half current electrode separation of $150 \mathrm{~m}$ have been used. The geoelectrical soundings were undertaken within the study areas between July and August, 2011. The Schlumberger method was used to acquire the soundings. The forms of the VES curves measured at the studied locations are of different types, indicating interplay between low and high resistivity layers (Figure 4). All resistivity soundings were invested using IPI $2 \mathrm{Win}$ software. This software performs an automated approximation of the initial resistivity model using the observed data [43]. All resulting models produced a low RMS relative error of the order of 3\%. The starting model used during the inversion of each of the measured VES locations were constrained according to obtained water table of the nearest water and available drillers log information. Five of the soundings closest to wells, where measured aquifer properties were available gave estimate of the Dar Zarrouk parameters (Table 1). 


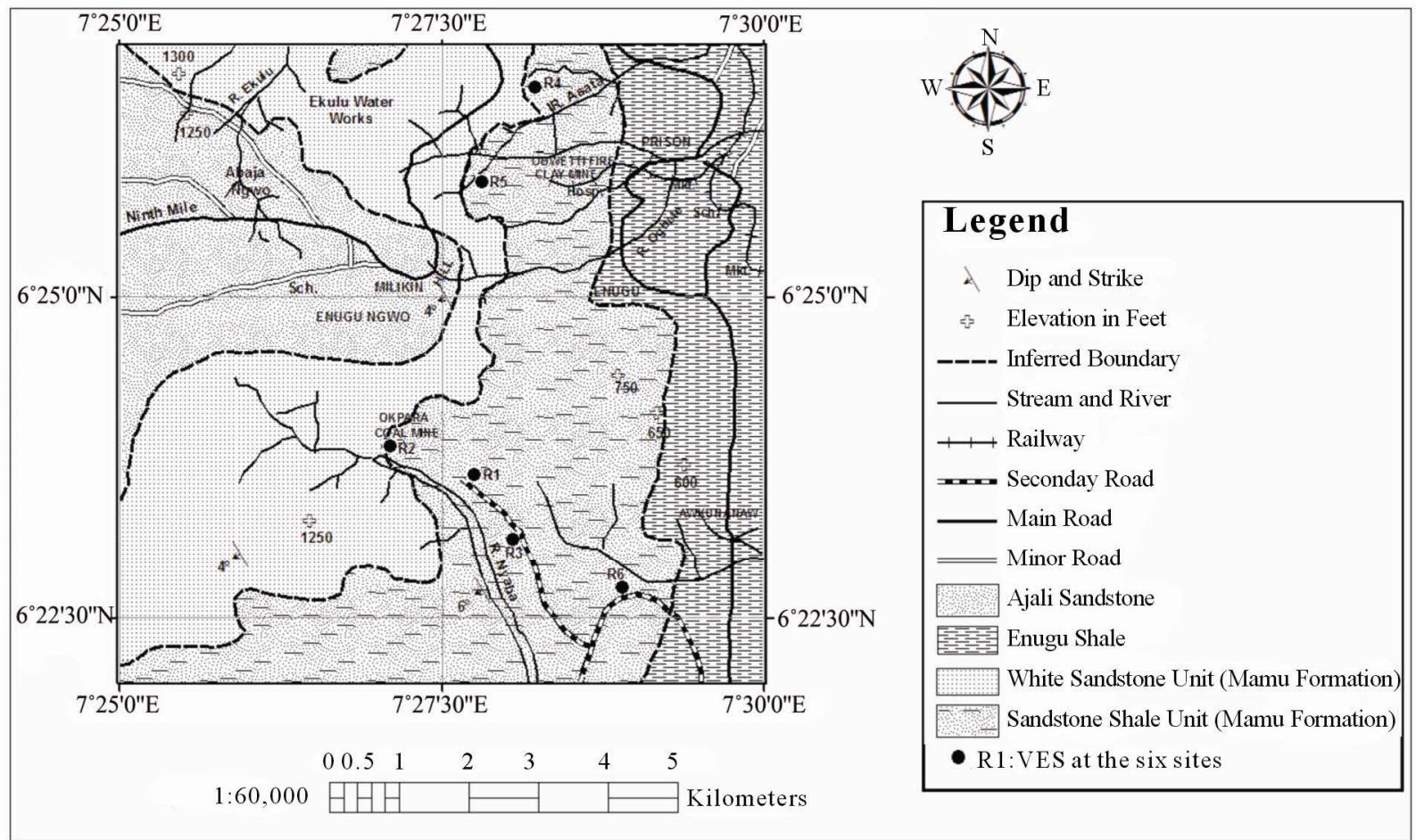

Figure 3. Physiographic and geologic map of the study also showing the location of the six VES points.

Table 1. Aquifer parameters and resistivity at six sites in parts of Enugu town (Nigeria).

\begin{tabular}{cccccc}
\hline VES Name & $\begin{array}{c}\text { Aquifer Thickness } \\
(\mathrm{m})\end{array}$ & $\begin{array}{c}\text { Aquifer } \\
\text { Resistivity } \\
(\Omega \cdot \mathrm{m})\end{array}$ & $\begin{array}{c}\text { Longitudinal Conductance } \\
\left(\Omega^{-1}\right)\end{array}$ & $\begin{array}{c}\text { Measured } \\
\text { Transmissivity } \\
\left(\mathrm{m}^{2} / \mathrm{d}\right)\end{array}$ & $\begin{array}{c}\text { Modeled } \\
\text { Transmissivity } \\
\left(\mathrm{m}^{2} / \mathrm{d}\right)\end{array}$ \\
\hline R1 & 9.0 & 527 & 0.017 & 696 & 470 \\
R2 & 2.1 & 55 & 0.038 & 162 & 511 \\
R3 & 6.6 & 354 & 0.019 & 635 & 525 \\
R4 & 8.2 & 364 & 0.023 & 162 & 836 \\
R5 & 2.1 & 68 & 0.031 & 302 & 857 \\
R6 & 3.9 & 127 & 0.031 & 558 \\
\hline
\end{tabular}

\section{Calculating the Aquifer Transmissivity}

The understudied aquifer system consists of fine grained, clayey-silty sand materials. Transmissivity of the studied aquifer is therefore assumed to be controlled by the thickness of the specific layer and the presence of fine/clay particles. Also, assuming that the longitudinal conductance is the dominant parameter, Equation (3) was used to calculate the transmissivity. The constant, $\beta$ was calculated using a linear regression taken between transmissivity and longitudinal conductance for the six locations where both data were available (Figure 5). The negative but strong statistical correlation between aquifer transmissivity and longitudinal conductance $\left(\mathrm{R}^{2}=0.82\right)$ highlights the applicability of the geoelectric sounding to the study area, giving a $\beta$ value of 0.32 . This relationship could be attributed to the influence of hydraulic and electrical anisotropy as well as the variations in the geology, grain size, as well as shape of pore channels. The transmissivity value at each of the 19 VES locations was then calculated using the longitudinal conductance from the resistivity survey.

Figure 6 shows the transmissivity distribution over the entire study area. It is clear that the highest transmissivity values are mostly on the northwestern part of the area and some parts in the southeastern part, identifying zones of high water bearing potential. Although details about the tectonic structure have not been defined in this study, 


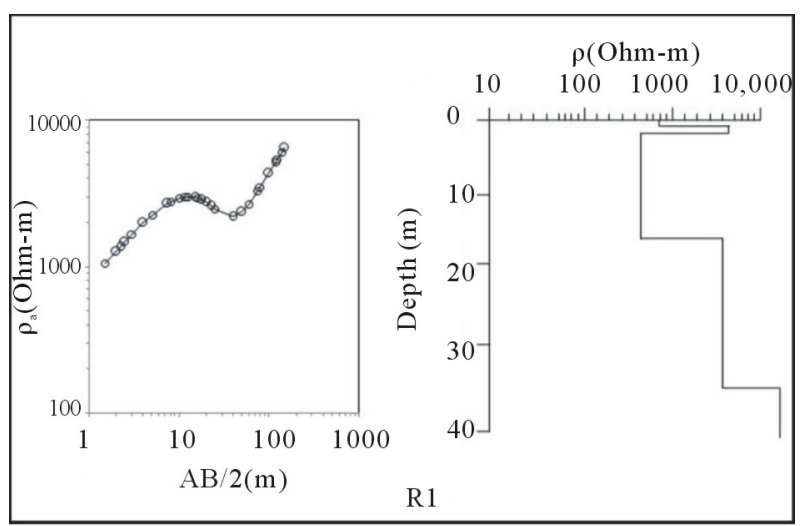

(a)

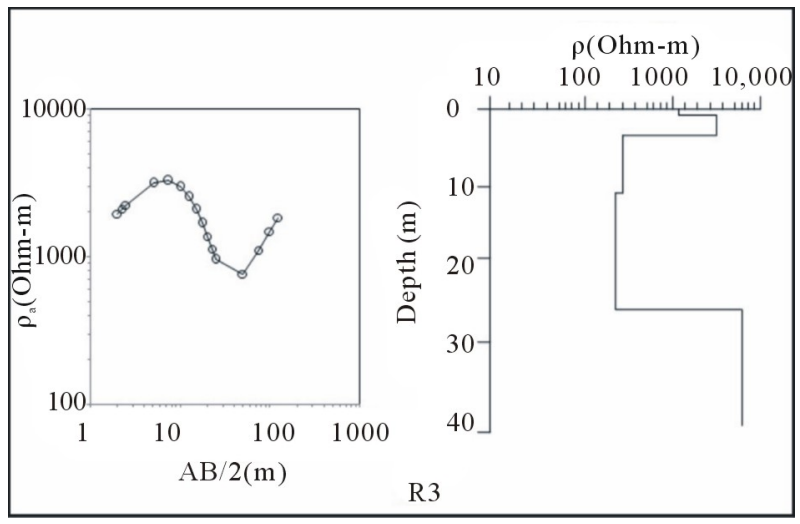

(c)

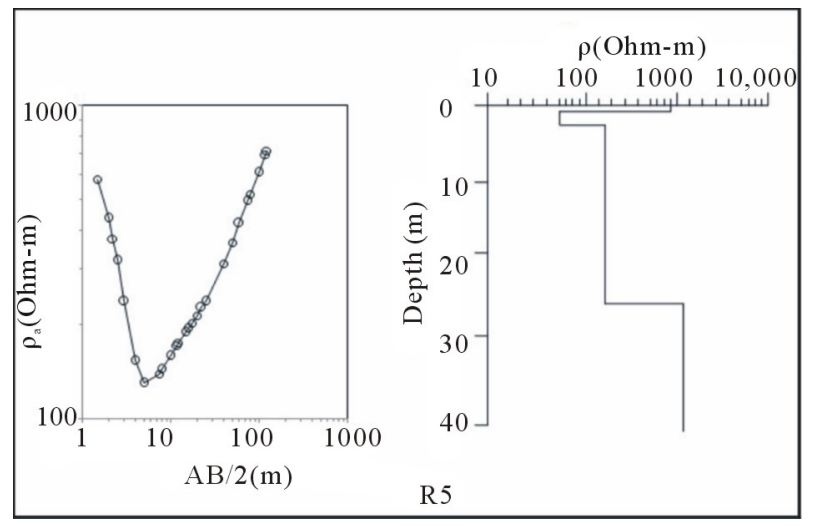

(e)

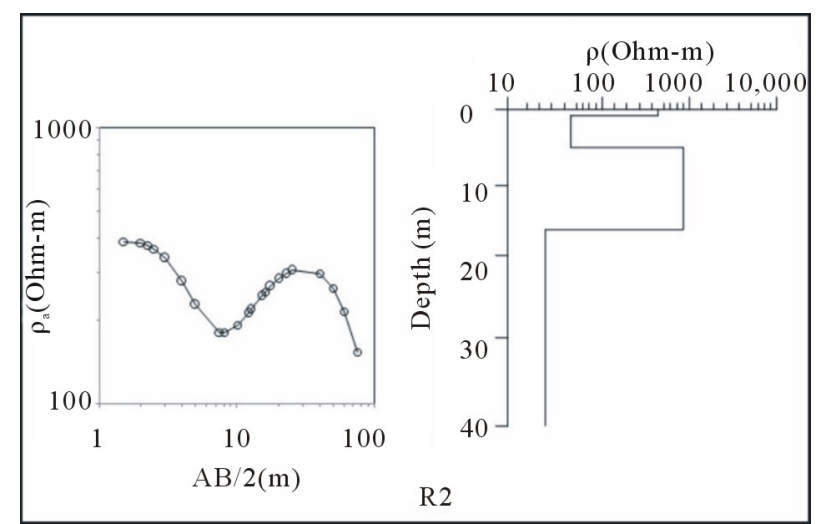

(b)

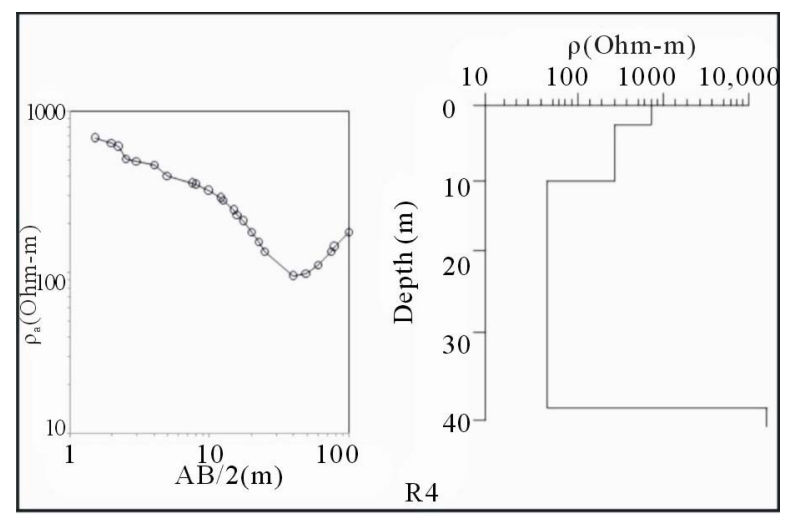

(d)

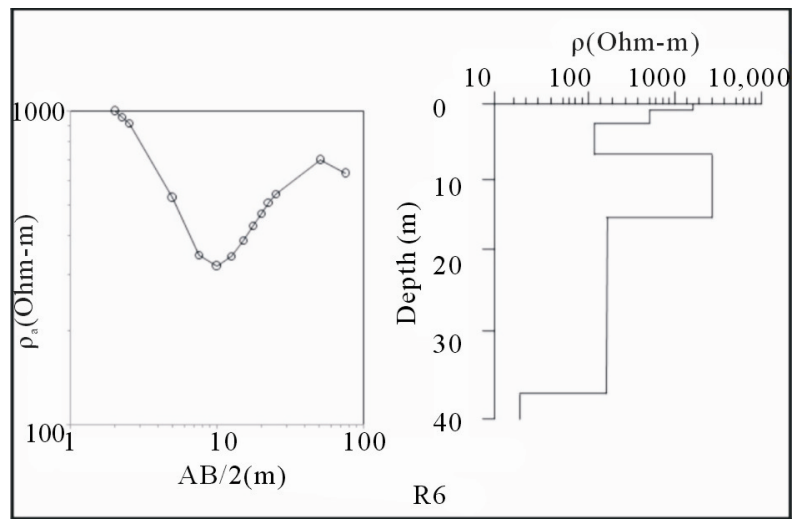

(f)

Figure 4. Resistivity soundings and interpretation at the six sites. Locations are shown in Figure 3.

it could be hypothesized that the disturbed nature of the fracture zones in the Enugu area ay be acting as boundaries between the same hydrolithological units and define the place the where aquifer parameter varies.

\section{Conclusion}

A rapid, simple relatively inexpensive and liable method of estimating the transmissivity distribution has been demonstrated in the Enugu area. The results of the study show useful estimation of the transmissivity and can be recommended when siting exploratory boreholes or as an initial input to a groundwater flow odel. Hydraulic conctivity information known at one point can be used to extrapolate the transmissivity over the area, which dends on the aquifer thickness and hydraulic conducvity.

Using Equation (3), it was necessary to establish a working relationship between transmissivity and the Dar Zarrouk parameter (longitudinal onductance) from which the value of $\beta$, was computed in the field for further modeling of the transmissivity values from the VES measurements. Effective application of this method like all 


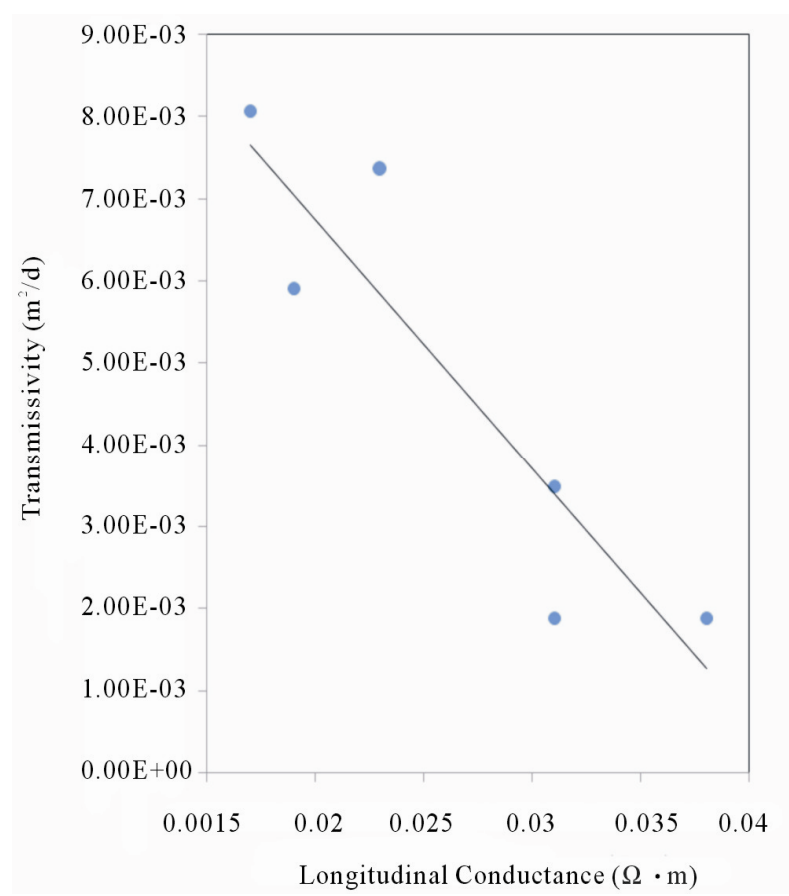

Figure 5. Longitudinal conductance and transmissivity at six sites in parts of Enugu town (Nigeria).

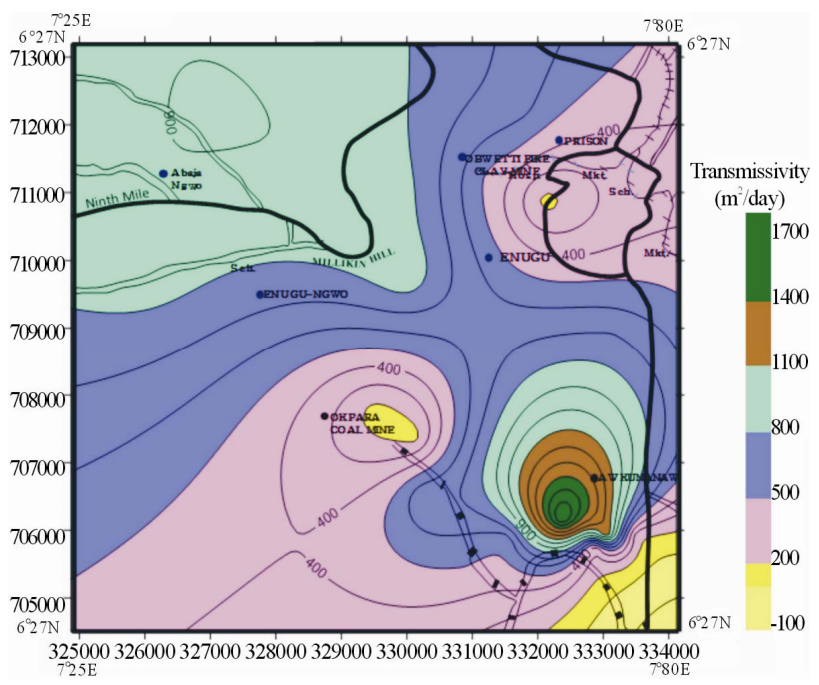

Figure 6. Contour map of the study area with transmissivity and physiography.

geophysical tool, however require a fair knowledge of the study site's geology and hydrogeogeology, which was taken into account. This technique employing the relationship between transmissivity and Dar Zarrouk parameters is well-founded and has been successfully applied by $[5,6,29,44]$. This technique could also assist in identifying parts of the aquifer with best potential yields and produce realistic ground water models especially in the Enugu area where small shallow aquifer are being increasingly developed for domestic water supply.

\section{Acknowledgements}

This paper is based on fieldwork by Ahamefula Utom carried out as part of the M.Sc. degree course in Applied Geophysics at the Nnamdi Azikiwe University (NAU), Nigeria. AAPG/Alexander \& Geraldine Wanek Grantsin-Aid and SEG Foundation Project of Merit Grant is acknowledged for financial support. Two anonymous reviewers and Prof. Boniface C. E. Egboka (NAU) are thanked for their helpful and invaluable comments on this manuscript.

\section{REFERENCES}

[1] W. K. Kosinki and W. E. Kelly, "Geoelectric Soundings for Predicting Aquifer Properties," Ground Water, Vol.19, No. 2, 1981, pp. 163-171. doi:10.1111/j.1745-6584.1981.tb03455.x

[2] J. F. Ayers, "Conjunctive Use of Geophysical and Geological Methods in the Study of Alluvial Aquifer," Ground Water, Vol. 27, No. 5, 1989, pp. 625-632. doi:10.1111/j.1745-6584.1989.tb00475.x

[3] D. J. Allen, L. J. Brewerton, L. M. Coleby, B. R. Gibb, M. A. Lewis, M. A. MacDonald, S. J. Wagstaff and A. T. Williams, "The Physical Properties of Major Aquifers in England and Wales," British Geological Survey Technical Report WD/97/34, 1997.

[4] F. G. Mendosa, S. T. Steenhuis, W. M. Todd and J. Y. Parlange, "Estimating Basin-Wide Hydraulic Parameters of a Semi-Arid and Mountainous Watershed by Recession-Flow Analysis," Journal of Hydrology, Vol. 279, No. 1, 2003, pp. 57-69. doi:10.1016/S0022-1694(03)00174-4

[5] S. Niwas, B. Tezkan and M. Israil, "Aquifer Hydraulic Conductivity Estimation from Surface Geoelectrical Measurements for Krauthausen Test Site, Germany," $\mathrm{Hy}$ drogeology Journal, Vol. 19, No. 2, 2011, pp. 307-315. doi:10.1007/s10040-010-0689-7

[6] A. M. MacDonald, J. Burleigh and W. G. Burgess, "Estimating Transmissivity from Surface Resistivity Soundings: An Example from the Thames Gravels," Quarterly Journal of Engineering Geology, Vol. 32, 1999, pp. 199205. doi:10.1144/GSL.QJEG.1999.032.P2.09

[7] A. Olayinka and R. Barker, "Borehole Siting in Crystalline Basement Areas of Nigeria with a Microprocessor-Controlled Resistivity Traversing System," Ground Water, Vol. 28, No. 2, 1990, pp. 178-183. doi:10.1111/j.1745-6584.1990.tb02244.x

[8] J. D. McNeil, "Use of Electromagnetic Methods for Groundwater Studies," In: S. H. Ward, Ed., Investigations in Geophysics No. 5 (Geotechnical and Environmental Geophysics, SEG Vol. II: Environmental Geophysics and Groundwater), Society of Exploration Geophysicists, Tulsa, 1990, pp. 191-218.

[9] R. M. Carruthers and I. F. Smith, "The Use of Ground Electrical Survey Methods for Siting Water Supply Boreholes in Shallow Crystalline Basement Terrains," In: E. P. Wright and W. D. Burgess, Eds., The Hydrogeology of Crystalline Basement Aquifers in Africa, Geological So- 
ciety, Special Publication, London, Vol. 66, 1992, pp. 203-220.

[10] M. P. Davies and R. G. Campanella, "Piezocone Technology: Downhole Geophysics for the Geoenvironmental Characterization of Soil," Proceedings of the SAGEEP Conference, Orlando, 26-29 April 1995.

[11] T. Dahlin, "2D Resistivity Surveying for Environmental and Engineering Applications," First Break, Vol. 14, No. 7, 1996, pp. 275-283.

[12] D. S. Parasnis, "Principles of Applied Geophysics," Chapman and Hall, London, 1997.

[13] I. A. Beresnev, C. E. Hruby and C. A. Davies, "The Use of Multielectrode Resistivity Imaging in Gravel Prospecting," Journal of Applied Geophysics, Vol. 49, No. 4, 2002, pp. 245-254. doi:10.1016/S0926-9851(02)00147-7

[14] A. Vchery and B. Hobbs, "Resistivity Imaging to DeterMine Clay Cover and Permeable Units at an Ex-Industrial Site," Near Surface Geophysics, Vol. 1, No. 1, 2003, pp. 21-30.

[15] A. Godio and M. Naldi, "Two-Dimensional Electrical Imaging for Detection of Hydrocarbon Contaminants," Near Surface Geophysics, Vol. 1, No. 3, 2003, pp. 131137.

[16] D. W. Urish, "The Practical Application of Surface Electrical Resistivity to Detection of Groundwater Pollution," Ground Water, Vol. 21, 1983, pp. 144-152. doi:10.1111/j.1745-6584.1983.tb00711.x

[17] M. A. Meju, "Geoelectrical Investigations of Old/Abandoned, Covered Landfill Sites in Urban Areas: Model Development with a Genetic Diagnosis Approach," Journal of Applied Geophysics, Vol. 44, 2000, pp. 115-150. doi:10.1016/S0926-9851(00)00011-2

[18] S. Niwas, P. K. Gupta and O. A. L. de Lima, "Nonlinear Electrical Response of Saturated Shaley Sand Reservoir and Its Asymptotic Approximations," Geophysics, Vol. 71, No. 3, 2006, pp. 129-133. doi:10.1190/1.2196031

[19] P.M. Soupios, M. Kouli, F. Vallianatos, A. Vafidis and G. Stavroulakis, "Estimation of Aquifer Hydraulic Parameters from Surficial Geophysical Methods: A Case Study of Keritis Basin in Chania (Crete-Greece)," Journal of Hydrology, Vol. 338, 2007, pp. 122-131. doi:10.1016/i.jhydrol.2007.02.028

[20] A. A. R. Zohdy, G. P. Eaton and D. R. Mabey, “Application of Surface Geophysics to Ground-Water Investigation," Techniques of Water Resources Investigation, US Geological Survey, 1974.

[21] W. E. Medeiros and O. A. L. de Lima, "A Geoelectrical Investigation for Groundwater in Crystalline Terrains of Central Bahia, Brazil," Ground Water, Vol. 28, 1991, pp. 518-523. doi:10.1111/j.1745-6584.1990.tb01707.x

[22] C. Akaolisa, "Aquifer Transmissivity and Basement Structure Determination Using Resistivity Sounding at Jos, Plateau State Nigeria," Environmental Monitoring and Assessment, Vol. 114, No. 1-3, 006, pp. 27-34.

[23] R. Sinha, M. Israil and D. C. Singhal, "A HydrogeoPhysical Model of the Relationship between Geoelectric and Hydraulic Parameters of Anisotropic Aquifers," $\mathrm{Hy}$ drogeology Journal, Vol. 17, 2009, pp. 495-503. doi:10.1007/s10040-008-0424-9

[24] A. T. Tizro, K. S. Voudouris, M. Salchzade, H. Mashayekhi, "Hydrogeological Framework and Estimation of Aquifer Hydraulic Parameter Using Geoelectrical Data: A Case Study from West Iran," Hydrogeology Journal, Vol. 18, No. 4, 2010, pp. 917-929.

doi:10.1007/s10040-010-0580-6

[25] S. Niwas and O. A. L. de Lima, "Aquifer Parameter Estimation from Surface Resistivity Data," Ground Water, Vol. 41, No. 1, 2011, pp. 94-99. doi:10.1111/j.1745-6584.2003.tb02572.x

[26] R. Dhakate and V. S. Singh, "Estimation of Hydraulic Parameters from Surface Geophysical Methods, Kaliapani Ultramafic Complex, Orissa, India," Journal of Environmental Hydrology, Vol. 13, No. 12, 2005, Paper 12.

[27] P. C. Heigold, R. H. Gilkeson, K. Cartwright and P. C. Reed, "Aquifer Transmissivity from Surficial Electrical Methods," Ground Water, Vol. 17, No. 4, 1979, pp. 338345. doi:10.1111/j.1745-6584.1979.tb03326.x

[28] W. E. Kelly and R. K. Frohlich, "Relations between Aquifer Electrical and Hydraulic Properties," Ground Water, Vol. 23, No. 2, 1985, pp. 182-189. doi:10.1111/j.1745-6584.1985.tb02791.x

[29] R. Frohlich and W. E. Kelly, "The Relation between Transmissivity and Transverse Resistance in a Complicated Aquifer of Glacial Outwash Deposits," Journal of Hydrology, Vol. 79, 1985, pp. 215-219.

[30] O. Mazac, M. Cislerova, W. E. Kelly, I. Landa, D. Venhodova, "Determination of Hydraulic Conductivities by Surface Geoelectric Methods," In: S. H. Ward, Ed., Investigations in Geophysics No. 5 (Geotechnical and Environmental Geophysics, SEG Vol. II: Environmental Geophysics and Groundwater), Society of Exploration Geophysicists, Tulsa, 1990, pp. 125-132.

[31] S. Niwas and D. C. Singhal, "Estimation of Aquifer Transmissivity from Dar-Zarrouk Parameters in Porous Media," Journal of Hydrology, Vol. 50, 1981, pp. 393399. doi:10.1016/0022-1694(81)90082-2

[32] S. Niwas and D. C. Singhal, "Aquifer Transmissivity of Porous Media from Resistivity Data," Journal of Hydrology, Vol. 82, No. 1-2, 1985, pp. 143-153.

[33] W. E. Kelly and P. F. Reiter, "Influence of Anisotropy on Relation between Electrical and Hydraulic Properties," Journal of Hydrology, Vol. 74, 1984, pp. 311-321. doi:10.1016/0022-1694(84)90021-0

[34] R. Maillet, "The Fundamental Equations of Electrical Prospecting," Geophysics, Vol. 12, No. 4, 1947, pp. 529556. doi:10.1190/1.1437342

[35] D. Huntley, "Relations between Permeability and Electrical Resistivity in Granular Aquifers," Ground Water, Vol. 24, No. 4, 1986, pp. 466-474. doi:10.1111/j.1745-6584.1986.tb01025.x

[36] G. E. Archie, "The Electrical Resistivity Log as an Aid in Determining Some Reservoir Characteristics," Transactions of the American Institute of Mining and Metallurgical Engineers, Vol. 146, No. 1, 1942, pp. 56-62.

[37] A. U. Utom, "Prediction of Shallow Aquifer Parameters and Water Quality in Okpara Coal Mine and Environs 
using Geoelectrical Sounding," M.Sc. Thesis, Nnamdi Azikiwe University, Awka, 2012, 106 p.

[38] G. I. Nwankwor, B. C. Egboka and I. P. Orajaka, "Groundwater Occurrence and Flow Pattern in the Enugu Coalmine Area, Anambra State, Nigeria," Hydrological Sciences Journal, Vol. 33, 1988, pp. 465-482. doi: $10.1080 / 02626668809491275$

[39] R. A. Freeze and J. A. Cherry, "Ground Water," Prentice Hall, Inc., New York, 1979.

[40] P. A. Domenico and F. W. Schwartz, "Physical and Chemical Hydrogeology," Wiley Press, New York, 1990.

[41] L. O. Sanni, "Cassava Post Harvest Needs Assessment
Survey in Nigeria," IITA, 2007.

[42] P. E. B. Inyang, “Climate Regions,” In: G. E. K. Ofomata, Ed., Nigerian in Maps, Eastern States, Ethiope Publishing House, Benin, 1975, pp. 27-29.

[43] C. Bobachev, "IPI2Win: A Windows Software for an Automatic Interpretation of Resistivity Sounding Data," PhD Thesis, Moscow State University, Russia, 2002.

[44] P. D. C. Mbonu, J. C. Ebeniro, C. O. Ofoegbu and A. S. Ekine, "Geoelectric Sounding for the Determination of Aquifer Characteristics in Parts of the Umahia Area of Nigeria," Geophysics, Vol. 56, No. 2, 1991, pp. 284-291. 